\title{
O ringue de Iúli Daniel
}

\author{
Marina Darmaros ${ }^{1}$
}

Resumo: Iúli Daniel nunca se considerou poeta, como relembra seu filho, Aleksandr, em introducão a este artigo. Mas, durante os cinco anos entre o cárcere e o gulag, o tradutor dedicou-se a uma produção autoral que resultou na publicação de uma coletânea de poemas, entre eles, "O ringue", aqui vertido do russo ao português pela primeira vez, apesar de sua figura ter ganbado alguma repercussão no Brasil ainda nos anos 1960, quando de sua prisão.

Palavras-chave: URSS, poesia, Estudos da Tradução, Literatura Russa

Abstract: Yuli Daniel never considered himself a poet, as his son Alexandr recalls in an introduction written exclusively to this article. But during five years he spent between jail and gulag, the translator devoted himself to an authorial production which resulted in the publication of a poem collection which included "The ring", translated here into Portuguese for the very first time although his figure have gained some repercussion in Brazil in the 1960s, when he was arrested.

Keywords: USSR, poetry, Translation Studies, Russian Literature

Аннотация: Как писал в предисловии к этой статье его сьин Александр, Юлий Ааниэль никогда не считал себя поэтом. Однако, в течение пяти лет между тюремныцм заключением и ГУ ААГом переводчик посвятил себя созданию авторских произведений, которые позже были опубликованы в формате сборника его стихов. В сборник воило и стихотворение «На ринге», перевод которого на португальский публикуется здесь впервыге, несмотря на то, ито в 1960-х годах, во время тюремного заключения автора, в Бразилии его фигура не оставалась безьгзвестной.

Ключевые слова: СССР, поэзия, переводоведение, русская литература

1 Marina Darmaros é mestra em Jornalismo Internacional pela Rossisski Universitet Drujbi Narodov e doutoranda no programa de Literatura e Cultura Russa da USP. Sua pesquisa atual, orientada pela Prof. Dra. Elena Vássina, está voltada ao cotejo da obra original de Jorge Amado com suas traduções para o russo na extinta União Soviética. Contato: marina.darmaros@usp.br 


\section{A produção autoral de um tradutor per se no cárcere}

Em 11 de fevereiro de 1966, o Jornal do Brasil publicou uma nota em posição privilegiada - no canto superior da capa, ou seja, não era preciso sequer desdobrá-lo para lê-la - sob o título "Escritores russos negam acusações". Tratava-se de um dos casos mais famosos no país acerca de intelectuais acusados de publicar no exterior literatura que difamava a União Soviética, relativo a Iúli Daniel e Andrêi Siniávski. Seu julgamento teve ressonância mundo afora e também no Brasil.

Nove dias depois, o mesmo jornal publicava, já no pé da página oito, a íntegra de um manifesto e os nomes de todos os mais de cem "intelectuais brasileiros" - entre eles, Antônio Callado, Millôr Fernandes, Dias Gomes, Fernanda Montenegro, Nelson Pereira dos Santos, Glauber Rocha - que subscreviam o texto:

Os intelectuais brasileiros, abaixo assinados, fiéis a sua luta em defesa da liberdade de pensamento e expressão, vêm manifestar seu repúdio à decisão da Justiça da URSS que condenou os escritores Andrei Sinyavski e Yuli Daniel por terem formulado críticas ao Governo daquele país. Enfrentando a arbitrariedade e o terrorismo cultural dentro de nossa Pátria, onde dezenas de intelectuais têm sido condenados, presos e perseguidos, não podemos aceitar, qualquer que seja a razão, a violência do Estado contra intelectuais em qualquer parte do mundo. Lamentamos que fatos como esse continuem a se verificar na URSS tantos anos depois da luta ali travada contra o obscurantismo stalinista. Reafirmamos nossa convicção de que só num clima de ampla e irrestrita liberdade podem florescer a cultura e a democracia (JoRnAl Do Brasil, 1966: 8).

O tribunal qualificou como crime, apesar do frisson global, o fato de Daniel ter escrito contos que atacavam o sistema soviético e publicá-los no exterior, "além disso, caluniando o prestígio da União Soviética sob os olhos dos países capitalistas" (tradução minha) ${ }^{2}$, como relembra o pesquisador Mark Hutcheson (1989). Publicando no exterior sob o pseudônimo de Nikolai Arjak, Daniel foi julgado, junto a Andrêi Siniávski, que assinava como Abram Terts, em fevereiro de 1966. Ambos foram condenados por uma corte criminal por traição à União Soviética. Ainda segundo aponta o Hutcheson, Daniel alegava que apenas a descontextualização de seus textos poderia levar a tais conclusões.

2 No original: “... secondly, by publishing these stories abroad and thus detracting from the Soviet Union's prestige in the eyes of capitalist countries". 
Em 1989, o pesquisador analisaria o caso de Daniel como “uma reabilitação de particular interesse" após a União Soviética "tornar-se tão tolerante com a poesia que poetas recitavam suas obras pelas ruas de Moscou" (tradução minha) ${ }^{3}$ na era Gorbatchov. A tendência, porém, já era anterior à glasnost e à Perestroika, como escreve, em introdução a minha tradução que se apresenta em seguida, direta do russo para o português, do poema "No ringue", o filho de Iúli, Aleksandr Daniel.

Em apêndice a seu artigo, Hutcheson (1989) notava também que:

Na edição de maio de 1989 da [revista] Ogoniók, [o poeta] Evguêni Evtuchenko diz que o senador Robert Kennedy lhe informou, durante sua visita a Nova York, em novembro de 1961, que a relação dos pseudônimos Arjak e Terts com Daniel e Siniávski foi revelada pela CIA à KGB. Claramente, sem essa informação, o julgamento nunca teria ocorrido. O motivo dos americanos era distrair a atenção de seus bombardeios no Vietnã. Outras fontes sugeriam que o próprio Kennedy era o responsável, dado que ele era um dos mais importantes difamadores da União Soviética durante o caso Daniel-Siniávski (tradução minha) $)^{4}$.

Hoje, passados 51 anos, infelizmente, a obra de Daniel, ao que parece, não encontrou eco em traduções para o português. E, ainda que qualquer condenação pela palavra escrita possa parecer cruel, o leitor lusófono ainda não pôde julgar por si próprio o teor dos escritos de Daniel.

Conquanto tragamos aqui um poema cunhado pelo escritor já durante o período em que se encontrava nos campos de trabalhos forçados, os chamados gulag, acreditamos que esta possa ser uma primeira contribuição para uma melhor compreensão do autor. A tradução que se apresenta em seguida, como já mencionado, é introduzida por texto cunhado por seu filho, Aleksandr Daniel, originalmente para esta edição da Cadernos de Literatura em Tradução, e vertido do russo ao português, com notas, por mim. Já o poema, traduzido também por

3 No original: “... one rehabilitation of particular interest" e "The Motherland herself is becoming so tolerant of poetry that poets reciting their work on the streets of Moscow are quite a common sight and literary clubs are flourishing".

4 No original: "In the May 1989 issue of Ogonyok Yevgeni Yevteshenko says that Senator Robert Kennedy informed him during his visit to New York in November 1961, that the pseudonyms Arzhak and Tertz had been linked by the C.I.A. to Daniel and Sinyavsky for the K.G.B. Clearly without this information the trial would never have taken place. The Americans' motive was to distract attention from their bombing campaign in Vietnam. Other sources suggest Kennedy himself was responsible, hypocritical backstabbing given that Kennedy was one of the most vociferous American detractors of the Soviet Union during the Daniel- Sinyavsky affair". 
mim, deve grandes agradecimentos ao olhar cauteloso do tradutor russo Dmítri Golub, que colaborou com sua revisão.

Como bem sabem todos os que têm algum interesse pelos estudos da tradução, verter um texto de uma língua a outra é uma escolha e uma "traição". No caso da tradução poética, isto é ainda mais patente. Ao verter "No ringue", quase sempre busquei manter-me fiel ao sentido, apesar de, para isso, conscientemente trair a forma. Gostaria que este primeiro esforço em verter Daniel, entretanto, fosse recebido como um incentivo para que outros tradutores também viessem a trabalhar este e muitos outros autores soviéticos que ainda carecem de versões em português.

\section{Introdução da tradução de “O Ringue” para a revista Cadernos de Literatura em Tradução (Aleksandr Daniel)}

Iúli Daniel nunca se considerou poeta. Inicialmente, também não se passava pela cabeça de Daniel ocupar-se sistematicamente da composição de versos. Salvo de quando em quando, como muitos em seu círculo, ele se permitia compor paródias em versos improvisadamente ou epigramas "ocasionalmente" - mas, como se pode supor, não levava a sério essas experiências. É verdade que ele introduzia com arte fragmentos poéticos em seus textos em prosa: na novela histórica inédita "Begstvo" (em tradução livre, "Fuga"), há versos estilizados ao século 18 (o tempo da ação da novela); capítulos da novela "Govorít Moskvá" (em tradução livre, "Fala Moscou") são abastecidos de epígrafes em versos assinadas por nomes de poetas inexistentes; no conto "Iskuplenie" (em tradução livre, "Expiação"), montam-se poemas e canções "compostos" por personagens da história. Apesar de todo o brilho dessas miniaturas em versos, elas foram pensadas como elementos da prosa e não pretendiam ter uma existência literária própria. (É verdade que, posteriormente, uma dessas miniaturas - a canção "Tsigânki”, em tradução livre, "Ciganas", executada por um dos protagonistas de "Iskuplenie" - foi musicada, concomitantemente, por vários músicos e, de repente, entrou para o folclore nacional).

Estritamente falando, ele não atribuía significado literário tampouco a sua prosa - aos três contos, "Ruki" ("Mãos"), "Tchelovek iz MINAPa" ("O homem do Instituto Moscovita de Profanação Científica") e "Iskuplenie", e uma novela

5 Nota de Aleksandr Daniel (daqui para frente, N.A.D.): Esta novela foi aceita para publicação em 1965 pela editora "Detgiz" e chegou a ser impressa em tipografia - mas então Daniel foi preso e toda a tiragem impressa, destruída. 
curta, "Govorít Moskvá" -, a mesma prosa que ele publicou em segredo no exterior sob o pseudônimo "Nikolai Arjak" e devido à qual foi condenado a cinco anos no campo de trabalhos forçados. Seu amigo Andrêi Siniávski, condenado junto com ele, formulou seu próprio projeto literário, que chamou de "realismo fantástico", e o concretizou vigorosamente em romances, novelas e contos de seu pseudônimo Abram Terts. Siniávski tinha entendido claramente que trilhava um novo caminho na literatura nacional. Já Daniel, lidava com grande respeito e admiração com o experimento literário de Siniávski-Terts sem, no entanto, proceder de qualquer projeto teórico: ele apenas experimentava a si próprio na literatura de ficção, não superestimando (imagine só, melhor seria ainda dizer subestimando sim) os resultados. Ele termina sua novela "Govorít Moskvá" com as palavras: "Penso que minha obra poderia ter sido escrita por qualquer outra pessoa de minha geração, de meu destino, já que eu também sou um amante deste detestável e belo país". A literatura de ficção não era a principal ocupação de sua vida: é interessante notar que ele sempre escreveu sua prosa limpa, sem borrões, rascunhos e versões, sujeitando os escritos apenas a edições estilísticas insignificantes. Às vezes me parece que toda a história com a "escrita secreta" era para ele, principalmente, uma aventura literário-biográfica, um incidente arriscado no mundo da filologia.

A verdadeira profissão literária de Iúli Daniel era a tradução poética, e ele lidava com essa sua profissão com extrema seriedade. Para dar o som adequado em russo a alguma oitava em língua estrangeira, ele podia se debruçar por semanas ou meses sobre uma tradução literal, alterando e jogando fora dezenas de versões, mergulhando, repetidas vezes, na arte do poeta traduzido, na cultura e na história do outro país. Com orgulho, ele chamava a si próprio de artesão da tradução poética, colocando no radical da palavra "artesão" seu significado primário, comercial-medieval e de agremiação.

Pretender a um título de poeta nem se passava pela cabeça de Daniel: ele colocava a poesia russa em uma posição alta demais, a mais alta possível, para fazê-lo.

Para mim, foi inesperado quando, em fevereiro de 1966, no primeiro encontro na solitária preventiva de Lefortovo, já após o julgamento e a condenação, meu pai nos informou, a mim e minha mãe, que começara a compor versos na prisão. Ele quis até mesmo ler para nós um deles, que, como disse, tinha "conteúdo puramente esportivo" - mas foi interrompido pelo vigilante carcereiro que presenciava o encontro. Possivelmente, era justamente o poema "Na ringue" (em tradução livre, "No ringue").

“O que o papai tem?”, eu perguntei a minha mãe enquanto saíamos do encontro. "O que há com ele, ele resolveu se reclassificar como poeta?”. "Não 
se afobe", respondeu filosoficamente minha erudita mãezinha. "Na prisão todos escrevem versos."

(Quando, dois anos e meio depois minha mãe, por sua vez, foi parar na prisão, eu relembrei, em um encontro, as palavras dela. "Todos, menos eu!", respondeu orgulhosamente ela.)

Realmente, o primeiro verso da prisão de Iúli Daniel dedicado aos amigos ("Vspomináite meniá. Iá vam vsem po stroke podaríu", ou "Lembrem-se de mim. Eu presentearei cada um com um verso") foi escrito por ele em setembro de 1965, alguns dias após sua detenção, na prisão preventiva de Lubianka ${ }^{6}$. Já seu último poema, que também se chama "Poslednee" ("Último"), foi escrito na prisão de Vladímir em agosto de 1970, algumas semanas antes de ser libertado. E acabou-se, meu pai nunca mais tratou de poesia.

Não, ele não tinha vergonha de sua obra poética. Em suas cartas enviadas do campo de trabalhos e da prisão de Vladímir, ele sempre a discutia com seus correspondentes, apesar de o tom geral dessas discussões ser moderado: era-lhe agradável quando os amigos elogiavam seus versos, mas quando os criticavam, ele também não guardava muita mágoa. Transcrevo alguns trechos dessas cartas:

"Resolvi decididamente que não escreverei em prosa aqui. O que escrevi, queimei. É mal e não o é. Não se pode, não se deve escrever impensadamente. Mas é muito estranho, e eu mesmo não entendo qual é o problema: escrevo versos sem grande cuidado, sem o 'editor interno'. Eis que é a isso que me limito - a meus versos e traducõos" ( $\mathrm{da}$ carta $\mathrm{N}^{\circ} 17$, datada de $16 / 11 / 1966)^{7}$

"Não tenho, ou praticamente não tenho amor-próprio de autor; pelo menos não em relação à poesia. De qualquer maneira, não me relaciono com quem quer que seja que diga qualquer coisa, exceto sobre as sinopses" (da carta $\mathrm{N}^{\circ} 54$, datada de 11/11/1968). ${ }^{8}$

"Não achei que fosse possivel lidar com isso tão seriamente e falar sobre isso tão profissionalmente. Apresentaram-me avaliaçoes cada vez mais simples: 'bem-sucedido e malsucedido', 'gosto ou não gosto'. Aí... bá uma grande conversa literária, completa, cabivel? [...] é estranho e não é do men feitio participar disto. E eu, com efeito, como pensava? Que tudo isso (não só

6 N.A.D. Andrêi Siniávski e Iúli Daniel estiveram entre os últimos prisioneiros desta conhecida prisão preventiva da URSS: no outono ela foi fechada e todos os que eram mantidos nela sob investigação, entre eles, Siniávski e Daniel, foram transferidos às solitárias preventivas da KGB em Lefortovo.

7 N.A.D. DANIEL, Iúli. "Iá vsio sbivaius na literaturu...". Pismá iz zakliutchenia. Stihi. Moscou: Memorial-Zvenia, 2000. p. 143.

8 N.A.D. Idem, p. 398. 
esses poemas, e não só poemas) era uma ilustração para mim”" (da carta $\mathrm{N}^{\circ}$ 68, datada de $18 / 12 / 1969){ }^{9}$

Levando em conta esses trechos, os poemas autorais de Daniel não eram para ele "Poesia com 'P' maiúsculo", mas somente um meio de expressão própria, um meio amplo e enérgico de comunicação com o mundo, sobretudo com os amigos. A verdadeira Poesia, segundo ele, não podia ser um meio, ela tinha um fim em si própria; de lá vem a dúvida sobre se o que ele escreve é realmente poesia. Mas a expressão própria e a comunicação são necessárias, porque Iúli Daniel precisa se assinalar publicamente, sua percepção do mundo de então, seu ponto de vista sobre o papel que ele acabava de desempenhar - o papel de herói de um notório processo político. Para Daniel, um homem excepcionalmente isolado, foi de uma estranheza profunda o papel de "figura pública". Mas já que o destino o levou a esse papel, ele não planejava se esquivar do destino - apesar de, ao mesmo tempo, ter a intenção de se distanciar com firmeza do pathos dissimulado que frequentemente se conjuga à "posição civil significativa socialmente". Existe, para um escritor que domine a pena, uma maneira melhor de declarar sua verdadeira posição que a poesia?

"... sei perfeitamente que não sou nenhum poeta lírico (nos versos, pelo menos), meus versos são declaratórios (o que, pensando bem, parece-me justamente agora que tem certo sentido) e, em geral, eles são uma condescendência por si sós. Escapo - 'amarro-me..” (da carta $\mathrm{N}^{\circ} 4$, datada de 20/4/1966) ${ }^{10}$.

Toda essa imagem mais espontânea se relaciona também ao poema " $\mathrm{Na}$ ringue" (em tradução livre, "No ringue") - uma metáfora ingênua e nem um pouco mascarada da oposição ao Comitê de Segurança Nacional, oposição pela qual o autor acabava de passar e que ele ainda enfrentaria.

Além disso, os versos são o gênero tecnicamente mais oportuno para prisões e campos de trabalhos forçados. Não é preciso ocultar a todo momento manuscritos receando uma súbita busca e confisco dos escritos, já que é fácil lembrar-se de versos. Depois, às vezes, pode-se libertar ${ }^{11}$ o material

9 N.A.D. Idem, p. 532-533.

10 Idem, p. 46.

11 Nota da tradutora Marina Darmaros, daqui para frente, N.M.D.: Aqui, Aleksandr Daniel emprega a palavra "vôlia" (“А потом, при случае, передать на волю”), que emprega novamente diversas vezes aо decorrer do texto com diferentes verbos e que não tem uma expressão exata em português. De origem protoeslava, "vôlia" não tem um correspondente preciso em português, aproximando-se tanto de "vontade própria" como de "liberdade". Nesse caso, "peredát na vôliu", ao pé da letra, significaria "transferir/passar à liberdade/vontade própria", e acredito que a personificação desses papéis que conseguiam "passar à liberdade", "ser libertados" seria a melhor escolha para essa terminologia em português. 
caso a censura do campo deixe passar por carta, ou, se não deixar, fazê-lo por algum canal "ilegal".

Fui apresentado aos poemas de meu pai em março de 1966, quando fomos pela primeira vez ao campo de trabalhos forçados da Mordóvia, ao chamado "encontro pessoal". Os encontros pessoais no campo, que tinha regime de alta segurança, aconteciam uma vez por ano (se haviam), com duração de 12 horas a três dias. Nós, desta vez, recebemos dois dias. Para tanto, entre a primeira e segunda fileira de arame farpado, foi construída a "casa dos encontros" - uma pequena construção de um andar e adjacente à guarda, com três ou quatro pequenos quartos em ambos os lados do longo corredor. Foi em um desses quartinhos que fomos jogados, e logo trouxeram também meu pai. Aqui viveríamos juntos por dois dias.

Meu pai encontrou uma maneira de trazer consigo ao encontro, passando pela revista obrigatória, algumas páginas de caderno em que, com a letra apertada, anotou seus poemas da prisão e os primeiros do campo de trabalhos forçados; então, ele já tinha cerca de duas dezenas deles. Naturalmente, ele próprio lembrava de seus versos mesmo sem cola; os textos anotados eram necessários para que nós tentássemos render-lhes a liberdade ${ }^{12}$ depois do encontro. Mas não havia qualquer certeza de que nós conseguíssemos isso: nós também deveríamos ser revistados na saída, após o encontro. Por isso, gastei parte do encontro relendo algumas vezes os poemas de meu pai e decorando-os. Consegui sem dificuldades: aos quinze anos, a memória é jovem e tenaz, e sempre lembrei-me de poesias com particular facilidade. (Resumindo, lembro desta seleção de versos ainda hoje, 50 anos depois, palavra por palavra). Também foi possível passar as anotações sem problemas: antes do final do encontro, sem pensar muito, enfiei-as na meia, calcei-me e saí para a área de guarda, soltando a cada passo um ruído suspeito. Claro que a qualquer revista mais ou menos cuidadosa os papéis com os poemas seriam inevitavelmente encontrados e confiscados. Felizmente, a revista desta vez foi bem superficial: ordenaram-me que tirasse os sapatos e checaram as botas, mas não me fizeram tirar as meias.

12 N.M.D.: Aleksandr faz novo uso de "vôlia" sobre os papéis, desta vez, conjugado com o verbo "vinesti” (retirar, passar): “... чтобы мы попытались после свидания вынести их на волю”. 
De um jeito ou de outro, os poemas se lançaram à liberdade,${ }^{13}$ foram trazidos para casa, datilografados na máquina de escrever e passados de mão em mão. $\mathrm{E}$ despertaram um interesse notável entre o público leitor. A seleção de poemas de Iúli Daniel pegou no misterioso mecanismo do samizdat,${ }^{14}$ no qual demanda e oferta são, em essência, a mesma coisa, como se fosse a rebuscada poesia do "século de prata", e penetrou de uma coleção particular a outra, multiplicando-se às dezenas, e, talvez, às centenas de exemplares - testemunho disto são os muitos arquivos de samizdat que se mantiveram até os nossos dias. Praticamente em qualquer um deles encontramos uma cópia datilografada dos poemas da prisão de Daniel. Mais ou menos no ano de 1967, esta seleção foi parar além das fronteiras, e foi publicada na revista de emigrantes russófonos "Grani".

Por que os poemas de Daniel, de repente, gozaram de popularidade? E qual quinhão dessa popularidade deve-se atribuir ao talento poético do autor, e qual ao interesse quanto à personalidade de um dos julgados no mais ruidoso processo político daqueles anos? O próprio Iúli Daniel deu sua opinião sobre isso de maneira bastante cética:

“... infelizmente, entendo perfeitamente que o interesse quanto aos meus poemas se deve muito ao autor, sua situação e condição. Transpus a felicidade de criar algo que existisse sozinho para o leitor, independente de mim." (da carta $N^{\circ} 43$, datada de 22/05/1968). ${ }^{15}$

O quanto ele estava certo ou errado, não cabe a mim julgar, mas aos leitores de seus versos.

No campo de trabalhos forçados e, depois, na prisão de Vladímir, para onde transferiram meu pai em 1969 por "mau comportamento", ele continuou a escrever versos. Ele anexou novamente sua obra poética em cartas, e a indulgente censura frequentemente não as liberava; às vezes, aliás, os censores desanexavam as inclusões poéticas e ele precisava reenviá-las usando diversos modos "ilegais". Já alguns poemas de caráter claramente publicístico ele nem tentava enviar por meios legais. Lembro-me de como, no outono de 1968, algum dos colegas de campo do meu pai trouxe-me uma caixa de fósforos dentro da qual, dobrada quatro vezes, havia uma ksiva ${ }^{16}$ - dois diminutos quartos de papel de cigarro. Nestes dois papei-

13 N.M.D.: No original, “Так или иначе, стихи вырвались на волю...”.

14 N.M.D. Cópias caseiras de livros proibidos. Mais sobre a prática e suas variações pode ser encontrado no seguinte artigo: https://br.rbth.com/arte/literatura/2017/07/11/os-homens-que-copiavam_800320

15 N.A.D. Idem, p. 330-331.

16 N.M.D.: Proveniente do iídiche, a palavra é utilizada em russo para designar anotação ou carta passada de maneira ilegal de cela em cela, de campo em campo e a partir da prisão para a liberdade, e vice-versa. 
zinhos microscópicos, com letras quase indistinguíveis a olho nu, estava inscrito um ciclo poético ou, melhor dizendo, o poema de Iúli Daniel "A v eto vrêmia..." ("E neste tempo..."), com quase 300 linhas; cada um dos nove poemas desse ciclo ocupava, em média, seis centímetros quadrados de papel. Isto foi resultado do trabalho, como eu soube depois, de um companheiro de campo do meu pai, Serguêi Mochkov; antes da prisão, Serguêi era um estudante do quinto ano da faculdade de biologia e tinha uma ótima experiência com preparados microscópicos. Eu não tinha tal habilidade, e passei alguns dias com a lupa decifrando essas inscrições. Outra ksivva que chegou mais tarde continha a tradução cunhada por meu pai de um poema do poeta letão Knuts Skuienieks, hoje reconhecidamente líder da literatura contemporânea letã, mas, naquele tempo, colega de campo de trabalhos forçados de Daniel. O poema, intitulado "Ne ogliádivaisia!" "Não olhe para trás!"), era em si próprio uma inversão da trama do mito da Antiguidade de Orfeu e Eurídice (Eurídice desce a Hades para retirar de lá o autor, Orfeu) e era repleto de alusões aos campos e reminiscências. Meu pai, de qualquer maneira, até no campo tentava, sobretudo, retornar a sua profissão literária principal: a de tradutor de poesia.

No que diz respeito a sua própria poesia autoral, em cinco anos de cativeiro Iúli Daniel reuniu quase meia centena de poemas independentes e aquele curto supramencionado. Tudo isso foi publicado na coletânea "Stikhí iz nevôli" ("Poemas do cativeiro”), que foi lançada em Amsterdã em 1971, logo após a libertação de Daniel da prisão. Relativamente há pouco tempo, já depois da morte de meu pai, fiquei sabendo que a publicação foi feita com seu conhecimento e sob seu consentimento.

Em liberdade, Daniel lidava com os resultados poéticos de seus cinco anos de "missão artística" da mesma maneira como o fazia durante a prisão: de maneira moderada, sem afetação, mas também sem se autodestruir. Quando pediam que ele declamasse seus poemas do campo e da prisão, ele o fazia, apesar de também sem grande desejo. Com grande prazer, porém, lia suas traduções feitas naquele mesmo período, do supracitado poema de Knuts Skuienieks até o clássico francês do século 19 Théophile Gautier, que traduziu na prisão de Vladímir. Quando foi libertado, ele se entregou completamente a sua principal ocupação literária, a tradução de poesia, e trabalhou muito e de maneira frutífera nessa esfera, realizando-a com alegria e deleite, apesar de as condições para publicação serem bastante humilhantes: ele só estava autorizado a publicar suas traduções sob pseudônimo (e não aquele, claro, sob o qual um dia publicou sua prosa "criminosa" além-fronteiras, mas outro, imposto pela KGB, Iúri Petróv). Iúli Daniel também não deixou, de maneira alguma, a prosa, apesar de já não haver retornado à literatura de ficção: até 
meados dos anos 1980, ele continuou o ciclo de miniaturas de memórias e ensaios pensados ainda na prisão de Vladímir, sob o título geral de "Svobôdnaia okhôta" ("Caça livre"). Mas, ao transpor o limiar dessa prisão em 12 de setembro de 1970 e sair para a liberdade, ele não compôs mais nem um único verso poético autoral (à exceção de diferentes tipos de improvisos cômicos, os quais todos fazemos de vez em quando). Jamais.

\section{На ринге}

Юлий Ааниэл

Я вышел, боксом не владея, Рискнув удачливой судьбой.

Не звал ни Бога, ни АюАей я И проигра^ до боя бой.

Толпа — грохочущая прорва, Перчатки — парою гранат... УАар! Я смят, отброшен, взорван, И спину мне обжег канат.

УАар! Бесстрастно смотрят судьи, Как дышит голая Ауша, Как Ао моей Ао тайной сути Аобрался мастер не спеша.

Он — бог. Его Авиженья четки, Как протоколы - без прикрас, И ставят черные перчатки УАары - точки после фраз.

Мне от беды не отвертеться, Меня везде достанет плеть, А все ж не будет полотенце У ног, постыдное, белеть!

Я жАу: сейчас меня накажут За Аерзость и за простоту.

\section{No ringue}

Iúli Daniel

Eu entrei, sem o boxe dominar, Arriscando um destino de sorte. Não invoquei Deus ou homem E perdi a luta antes de lutar.

A multidão - estrondosa massa, As luvas - um par de granadas...

Golpe! Eu aniquilado, lançado, arrebentado, E o cordão minhas costas a queimar.

Golpe! Impassivelmente assistem os juízes Como respira uma alma nua, Como, sem se apressar, o mestre minha essência secreta extenua.

Ele é deus. Seus movimentos, precisos, Como protocolos - sem invencionices, $\mathrm{E}$ as luvas negras a deixar Golpes - pontos depois das frases.

Eu da desgraça não escapo, Por todo o lado o açoite a me alcançar, Mas, pelo menos, toalha não haverá às pernas, vergonhosa, a branquear!

Espero: agora serei castigado Pelo atrevimento e pela simplicidade. 
Ну что же - бей! Пускай нокаут

Под схваткой подведет черту.

Я поражение Аюбое

Приму, зажав зубами крик,

Не Аля победы, а Аля боя

Я шел на ринг.
E então?! Bata! Deixe o nocaute

colocar o ponto final no combate.

Eu qualquer derrota aceito

Cerrando com os dentes o grito,

Não é pela vitória, mas pela luta

Que o ringue eu adentro.

\section{Предисловия к журнальной публикации стихотворения Ю.М.Ааниэмя “На ринге” (Александр Ааниэк)}

ЮАий Ааниэль никогда не считац себя поэтом. Ао поры, Ао времени Ааниэлю и в голову не приходило заниматься стихотворчеством систематически. Разве что изредка, как многие в его кругу, он позволял себе экспромтом сочинить стихотворный шарж или эпиграммы «к случаю» - но, разумеется, серьезно к этим опытам не относицся. Правда, он мастерски встав ял поэтические фрагменты в свои прозаические тексты: в неопубликованной исторической повести «Бегство» ${ }^{17}$ встречаются вирши, стилизованные поА XVIII век (время действия повести); главы повести «Говорит Москва» снабжены стихотворными эпиграфами, подписанными именами несуществующих поэтов; в рассказ «Искупление» вмонтированы стихи и песни, «сочиненные» персонажами повести. При всем блеске этих стихотворных миниатюр, они задумывацись как элементы прозы и на самостоятельное митературное существование не претендовали. (Правда, впоследствии одна из таких миниатюр, - песня «Цыганки», исполняемая одним из героев «Искупления», - была положена на музыку одновременно несколькими исполнитецями авторской песни и неожиданно вошла в городской фольклор).

Строго говоря, и прозе своей, - трем рассказам («Руки», «Человек из МИНАПа», «Искупление») и одной небольшой повести («Говорит Москва»), - той прозе, которую он тайно публиковац за рубежом поА псевдонимом «Николай Аржак», и за которую получим пять мет магерей, он не придавац большого Аитературного значения. Его Аруг и «одноделец»

17 Эта повесть в 1965 году была принята к публикации в издательстве «Аетгиз» и даже отпечатана в типографии - но тут Ааниэля арестова^и и весь отпечатанный тираж пошем «по нож». 
Андрей Синявский выработал собственный митературный проект, который назвац «фантастическим реализмом» и мощно реализовац этот проект в романах, повестях и рассказах своего Аитературного Авойника Абрама Терца. Синявский отчетливо понимал, что прокладывает новый путь в отечественной Аитературе. Ааниэль же, с огромным пиететом и восхищением относившийся к митературным экспериментам СинявскогоТерца, сам ни из каких теоретических проектов не исходил; он просто пробовац себя в белметристике, не слишком переоценивая (пожалуй, скорее, недооценивая) результаты. Свою повесть «Говорит Москва» он заканчивает словами: «Я Аумаю, что написанное мною могло быть написано Аюбым Аругим человеком моего поколения, моей судьбы, так же, как и я $\Lambda$ юящим эту проклятую, эту прекрасную страну». Бемлетристика не была главным делом его жизни: интересно, что прозу он писал всегда

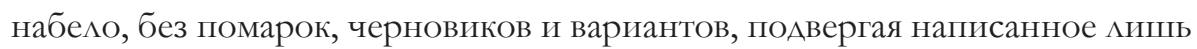
незначительному стилистическому редактированию. ИногАа мне кажется, что вся история с «тайным писательством» была Аля него, главным образом, митературно-биографической авантюрой, рискованным приключением в мире словесности.

Настоящей митературной профессией ЮАия Ааниэля был поэтический перевоА, и к этой своей профессии он относился предельно серьезно. Ради того, чтобы добиться адекватного звучания на русском какогонибудь иноязычного восьмистишия, он мог неделями и месяцами сиАеть наА подстрочником, перебирать и отбрасывать десятки вариантов, вновь и вновь погружаться в творчество переводимого поэта, в культуру и историю Аругой страны. Он с гордостью называл себя ремесленником поэтического перевода, вкладывая в слово «ремесло»его первоначальное, торжественносредневековое, цеховое значение.

А претендовать на звание поэта Ааниэлю Ааже не приходило в голову: он слишком высоко, выше всего на свете, ставиц русскую поэзию, чтобы решиться на такое.

Аля меня было неожиданностью, когда в феврале 1966, на первом свидании в Аефортовском следственном изоляторе, уже после суда и приговора, отец сообщи нам, - моей матери и мне, - что в тюрьме он стал сочинять стихи. Он Ааже хотел прочесть нам одно из них, - как он выразился, «чисто спортивное по содержанию», - но был остановлен бАительным наАзирателем, присутствовавшим на свиАании. Наверное, это как раз и было стихотворение «На ринге». 
«Что это с папой?», - спросих я у матери, выйдя со свидания. - «Он, что, решил переквалифицироваться в поэты?». «Не волнуйся», - фи ософски ответила моя эрудированная матушка. - «В тюрьме все пишут стихи».

(КогАа Ава с половиной года спустя моя мать в свою очередь попала в тюрьму, я на свидании напомниц ей эти слова. «Все - но не я!», - гордо сказала она.)

И в самом деле: первое тюремное стихотворение Юлия Ааниэля, обращенное к Арузьям («Вспоминайте меня. Я вам всем по строке подарю») было написано им в сентябре 1965 года, через несколько Аней после ареста, в Аубянской следственной тюрьме ${ }^{18}$. Пос $е$ енее же стихотворение, которое так и называется - «Последнее» («Этот гоА пройдет с пустой котомкой»), писалось во ВАаАимирской тюрьме в августе 1970-го, за пару недель до выхода на свободу. Все, больше мой отец к поэзии никогда не обращался.

Нет, он не стеснялся своего поэтического творчества. В своих письмах из мордовского Аагеря и ВАаАимирской тюрьмы он часто обсужАает его со своими корреспондентами, хотя общая тонаАьность этих обсуждений сдержанная: ему приятно, когда Арузья хвацят его стихи, но когда их ругают, он тоже не очень огорчается. Приведу несколько цитат из этих писем:

Я твердо решил, что писать прозу я здесь не буду. То, что написал, - сжег. Плохо и не то. Нельзя, невозможно писать с оглядкой. Но очень странно, сам не пойму, в чем дело: стихи пишу без всяких оглядок, без «внутреннего редактора». Вот этим и ограничусь - своими стихами и переводами (из письма №17, запись от $16 / \mathrm{XI}-66){ }^{19}$

«У меня нет или почти нет авторского самолюбия, во всяком случае, применительно к стихам. Все равно, кто бы что бы ни говорил, иначе как к конспектам я к ним не отношусь» (из письма №54, запись от 11/XI-68). ${ }^{20}$

«Я не думал, ито к этому можно относиться так всерьез и говорить об этом так профессионально. Мне как-то все больше простенькие оченки представлялись: «удачно — неудачно», «нравится — не нравится». А тут... Полно, уместен ли большой литературный разговор? <..> ...страшно и не по чину мне в этом участвовать. Я

18 Андрею Синявскому и Юлию Ааниэлю выпало стать едва Аи не последними узниками этой самой знаменитой в СССР следственной тюрьмы: осенью она была закрыта, а всех содержавшихся в ней подследственных, в том числе Синявского и Ааниэля, перевели в слеАственный изолятор КГБ в $\Lambda$ ефортово.

19 Юлий Ааниэль. «Я все сбиваюсь на Аитературу...». Письма из заключения. Стихи. - М.: «Мемориал»-«Звенья», 2000. - С.143.

20 Там же, с.398. 
ведь как думал? Все это (не только эти стихи и не только стихи) - иллюотрауия ко мне» (из письма №68, запись от 18/XII-69). ${ }^{21}$

Судя по этим цитатам, собственные стихи Аля Ааниэля не «Поэзия с большой буквы», а мишь средство самовыражения, емкое и энергичное средство коммуникации с миром, прежде всего - с Арузьями. Настоящая же Поэзия, по его мнению, не может быть средством, она самоценна; отсюда постоянные сомнения в том, Аействительно $и$ то, что он пишет, настоящая поэзия. А самовыражение и коммуникация необходимы, ибо ЮАию Ааниэлю необходимо публично обозначить себя, свое нынешнее мироощущение, свой взгляА на роль, которую он только что сыграл - роль героя громкого политического процесса. Ааниэлю, сугубо частному человеку, была глубоко чужАа роль «общественного деятеля». Но коль скоро судьба привела его к этой роли, он не собирается уклоняться от судьбы - однако при этом намерен твердо Аистанцироваться от можного пафоса, часто сопрягаемого с «общественно значимой гражАанской позицией». Есть $\Lambda и$ Аля Аитератора, владеющего пером, Аучшее средство Аекларировать свою истинную позицию, чем стихи?

«...отлично знан, что никакой я не лирик (в стихах, по крайней мере), вирши мои декларативны (что, впрочем, именно сейчас кажется мне имеючим определенньй смьгл) и вообще они — поблажка самому себе. Выгберус на волю — «завяжу»» (из письма №4, запись от 20/IV-66). ${ }^{22}$

Все это самым непосредственным образом относится и к стихотворению «На ринге» - нехитрой и нисколько не замаскированной метафоре противостояния с Комитетом госбезопасности, того, противостояния, через которое автор только что проше , и того, которое ему еще предстоит.

Кроме того, стихи - технически самый подходящий жанр Аля тюрьмы и магеря. Не надо прятать и перепрятывать рукописи, опасаясь внезапного обыска и изъятия написанного, ибо стихи мегко запомнить. А потом, при случае, передать на волю, если магерная цензура их пропустит, - в письме, если нет - по какому-нибудь «нелегальному» каналу.

21 Там же, с.532-533.

22 Там же, с.46. 
С тюремными стихами отца я познакомился в марте 1966, когда мы впервые приехали в мордовский Аагерь на так называемое «личное свидание». Аичные свидания в Аагерях строгого режима Аавали (если Аавали) раз в гол, Алительностью от полусуток до трех; нам в тот раз Аали Авое суток. Аیя этого межАу первым и вторым рядами колючей проволоки, опоясывающей магерь, был выстроен «Аом свиданий» - примыкающее к вахте небольшое одноэтажное строение, с тремя или четырьмя маленькими комнатками по обе стороны Алинного коридора. В одну из этих комнаток нас и запустили, а вскоре сюда привели и отца. ЗАесь нам предстояло прожить вместе Авое суток.

Отец ухитрился пронести с собой на свиАание через обязательный обыск несколько тетрадных мисточков, на которых убористым почерком записал свои тюремные и первые Аагерные стихотворения; к этому времени их у него около Авух десятков. Сам он, естественно, помнил свои стихи и без шпаргалки; записанные тексты нужны были А^я того, чтобы мы попытались после свидания вынести их на волю. ОАнако, уверенности в том, что у нас это получится, не было никакой: нас ведь тоже должны были после свидания обыскать на выходе. Поэтому часть свидания я потратил на то, чтобы несколько раз перечитать отцовские стихи и запомнить их наизусть. Это удацось без труда: в пятнаццать мет память молодая и цепкая, а стихи я всегда запоминац особенно мегко. (Впрочем, эту стихотворную подборку я и сегодня, через 50 Ает, помню слово в слово). Записи тоже удацось вынести без проблем: перед окончанием свидания я, недолго Аумая, запихнул их в носок, обулся и пошел на вахту, издавая на каждом шагу подозрительное шуршание. Конечно, при Аюбом мало-мальски Аобросовестном обыске Аисточки со стихами были бы неизбежно обнаружены и изъяты. К счастью, обыск в тот раз был весьма поверхностным: мне приказали разуться и проверили ботинки, но носки снимать не заставили.

Так или иначе, стихи вырвались на волю, были привезены домой, перепечатаны на пишущей машинке и пошли по рукам. И вызвали неожиданно заметный интерес у читающей публики. Загадочный механизм «самиздата», в котором спрос и предложение суть одно и то же, подхватил подборку тюремных стихотворений ЮАия Ааниэля, как если бы это была изысканная поэзия «серебрянного века», и понес их от одной Аомашней кол екции к Аругой, на ходу размножая ее в десятках, а, может быть, сотнях экземпляров - об этом сегодня свидетельствуют многочисленные Аичные

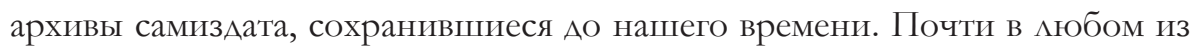
них мы находим машинописные копии тюремных стихов АаниэАя. Году 
примерно в 1967 эта подборка попала уже и за границу, и была опубликована в русскоязычном эмигрантском журнале «Грани».

Почему стихи Ааниэля неожиданно приобрели популярность? И какую Аолю этой популярности следует отнести на счет поэтического таланта автора, а какую - на счет общественного интереса к Аичности одного из

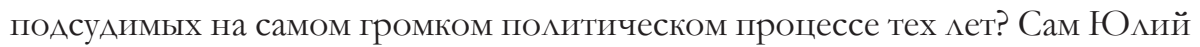
Ааниэль высказывался по этому поводу Аовольно скептически:

«...увъг, я очень хорошо пониман, что в интересе, проявляемом кмоим стихам, слишком много приходится на долю автора, его положения и состояния. Меня миновало счастье создать вещь, которая сушествовала бь для читателя отдельно и независимо от меня) (из письма №43, запись от22/V-68). ${ }^{23}$

Насколько он был прав или неправ - судить не мне, а читателям его стихотворений.

В магере, а потом и во ВАалимирской тюрьме, куда моего отца перевели в 1969 году за «плохое поведение», он продолжал писать стихи. Вновь сочиненные стихотворения он вклаАывац в письма, и снисходительная цензура чаще всего их пропускаца; иногда, впрочем, стихотворные

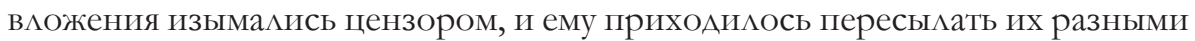
«нелегальными» способами. А некоторые стихи явно публицистического характера он и не пытался посылать мегально.

Lembro-me de como, no outono de 1968, algum dos colegas do meu pai, ao deixar o campo de trabalhos forçados, trouxe-me uma caixa de fósforos dentro da qual, dobrada quatro vezes, havia uma ksíva

Помню, как осенью 1968 года кто-то из освободившихся солагерников отца принес мне спичечный коробок, в котором, сложенная вчетверо, лежала «ксива» - Аве крохотных четвертушки папиросной бумаги. На этих Авух $и$ иточках микроскопическими, почти неразАичимыми невооруженным глазом буковками бы записан стихотворный цикл или, скорее, поэма ЮАия Ааниэля «А в это время...», объемом более 300 строк; каждое из девяти стихотворений этого цикла занимало в среднем 6 кв.см мистка. Это была, как я узнал позднее, работа магерного товарища моего отца, Сергея Мошкова; перед арестом Сергей был студентом 5 курса биологического факультета и име отличные навыки работы с микроскопическими препаратами. Я такого навыка не имел и провел с ^упой несколько Аней, расшифровывая эту запись.

23 Там же, с.330-331. 
Аругая «ксива», пришедшая позднее, содержала сделанный отцом перевод поэмы матышского поэта Кнута Скуениекса, ныне - признанного мидера современной матышской Аитературы, а в то время - солагерника Ааниэля. Поэма называцась «Не оглядывайся!», представляла собой сюжетную инверсию античного мифа об Орфее и Эвридике (Эвридика спускается в АиА, чтобы вывести оттуда автора - Орфея) и была переполнена «лагерными» алАюзиями и реминисценциями. Отец мой все-таки Ааже в магере больше всего стремился вернуться к своей основной Аитературной профессии поэтическому переводу.

Что касается собственной оригинальной поэзии, то за пять Ает неволи у Юлия Ааниэля набралось около полусотни отдельных стихотворений и одна небольшая поэма, упомянутая выше. Все это было опубликовано в сборнике «Стихи из неволи», вышедшем в Амстердаме в 1971 году, вскоре после освобождения Ааниэля из заключения. Сравнительно недавно, уже после смерти отца, мне стало известно, это издание состоялось с его веАома и согласия.

На свободе Ааниэль относился к поэтическим результатам своей пятилетней «творческой командировки» так же, как и в заключении: сдержанно, без аффектации, но и без самоуничижения. КогАа его просили почитать свои магерные и тюремные стихи - читал, хотя и без особой охоты. С куда большим удовольствием он читал свои переводы, сделанные в тот же период, от названного выше перевода поэмы Кнута Скуениекса до французского классика XIX века Теофиля Готье, которого он переводил во ВАадимирской тюрьме. ВыйАя на свободу, он полностью отАал себя

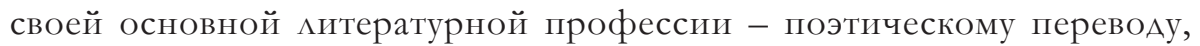
работал в этой области много и плодотворно, занимался этим радостно и с наслаждением, хотя условия публикации были довольно унизительными: ему разрешено было публиковать свои переводы только под псевдонимом ( не тем, разумеется, под которым он когда-то печатал за границей свою «криминальную» прозу, а под Аругим, навязанным КГБ - «Ю.Петров»). Прозу Юлий Ааниэль тоже не вовсе оставиц, хотя к беллетристике уже не вернулся: Ао середины 1980-х он продолжал задуманный еще во ВАадимирской тюрьме цикл мемуарно-эссеистических миниатюр под общим названием «Свободная охота». Но, перешагнув 12 сентября 1970 порог этой тюрьмы и выйАя на волю, он не сочинил больше ни одной собственной поэтической строчки (за исключением разного рода шуточных экспромтов, которые все мы слагаем от случая до случая). Никогда. 


\section{Referências}

Daniel, Iúli. Iá vsio sbivaius na literaturu... Pismá iz zakliutchenia. Stibi. Moscou: Memorial-Zvenia, 2000. p. 143.

Hutcheson, Mark. Russian Poetry and Glasnost: A Case Study. The Poetry Ireland Review. No. 26 (Summer, 1989), pp. 62-67.

JORNAL DO BRASIL. Escritores russos negam acusações. 11/02/1966, p. 8.

Jornal Do Brasil. Brasileiros defendem escritores. 20/02/1966, p. 8.

\section{Publicações eletrônicas:}

https://br.rbth.com/arte/literatura/2017/07/11/os-homens-que-copiavam 800320 